\title{
IDENTIFIKASI MEDICATION ERROR FASE COMPOUNDING PADA PASIEN ANAK RAWAT JALAN DI RSUD LABUANG BAJI MAKASSAR
}

\author{
Raimundus Chaliks ${ }^{1}$, Rusli ${ }^{1}$, Nurul Hasanah ${ }^{1}$ \\ ${ }^{1}$ Jurusan Farmasi Poltekkes Kemenkes RI Makassar \\ e-mail: roykhaik@gmail.com
}

DOI: https://doi.org/10.32382/mf.v13i2.829

\section{ABSTRAK}

Compounding error adalah suatu kesalahan yang terjadi pada proses peracikan, peracikan obat umumnya menjadi solusi terhadap keterbatasan formula obat untuk anak, yang berkaitan dengan medication error (ME). Tujuan penelitian ini untuk mengidentifikasi kejadian ME fase compounding. Penelitian ini merupakan penelitian observasional deskriptif rangcangan penelitian adalah cross sectional study. Hasil penelitian menemukan bahwa terjadi kesalahan pada Kebersihan alat dan meja racik 19,33\%, obat tumpah pada saat pembuatan kapsul/puyer 14,66\%, tidak mencuci tangan/memakai sarung tangan pada saat meracik obat 19,33\%, perhitungan obat yang kurang akurat (seperti dibelah) 13,33\%, dosis kurang karena menempel pada mortir dan blender 13,33\%, dan meracik menggunakan blender $11,33 \%$. hasil penelitian menyimpulkan bahwa terjadi medication error pada fase compounding.

\section{Kata kunci : medication error, compounding error}

\section{PENDAHULUAN}

Populasi pediatrik merupakan
tantangan bagi penyedia pelayanan kefarmasian, meliputi sedikitnya informasi yang terpublikasi dalam hal penggunaan obat, kurangnya ketersediaan formula bentuk sediaan maupun konsentrasi obat yang cocok untuk anak (Ceci et al., 2009). Peracikan obat umumnya menjadi solusi terhadap keterbatasan formula obat untuk anak. Peracikan menjadi perhatian oleh karena banyak munculnya kejadian yang tidak dikehendaki meliputi kesalahan pengobatan, kualitas racikan, serta masalah kontaminasi bakteri (Allen, 2003).

Peracikan sering berkaitan dengan medication error (ME) atau masalah kesalahan dalam pengobatan. Overdosis dari penggunaan clonidin telah dilaporkan sebagai akibat dari ME saat peracikan obat (Romano \& Dinh, 2001).

Medication error didefinisikan sebagai suatu kesalahan yang terjadi pada waktu pengobatan yang bisa menyebabkan kerugian atau berpotensi menyebabkan kerugian pada pasien, yang sebetulnya dapat dicegah. Peracikan yang mempengaruhi dosis ini termasuk ME. Berdasarkan kejadian yang sering di jumpai pada tahap compounding (peracikan) meliputi: kebersihan alat dan meja meracik, obat tumpah pada saat pembuatan kapsul /puyer, tidak mencuci tangan /memakai sarung tangan pada saat meracik obat, tablet yang seharusnya tidak di puyerkan seperti tablet salut, perhitungan obat yang kurang akurat (seperti dibelah), dosis kurang karena menempel pada mortir dan blender, meracik menggunakan blender. Menurut hasil penelitian yang dilakukan Erline Yusticia Hinlandou (2007), "tentang evaluasi medication error resep racikan pasien pediatrik di instalasi farmasi rawat jalan dirumah sakit bethesda yogyakarta, hasil penelitian menunjukkan bahwa terjadi kesalahan pada pengambilan obat $(6,8 \%)$; peracikan $(4,6 \%)$; pelabelan $(0,4 \%)$; kalkulasi dan rekalkulasi dosis $(1,5 \%)$; dan pengemasan $(0,2 \%)$; serta penyebutan nama pasien $(0,2 \%)$. Kesimpulannya yaitu pada tahap proses coumpouding terjadi $\mathrm{ME} \pm 22.2 \%$. Penelitian ini bertujuan untuk mengidentifikasi kejadian ME fase compounding

\section{METODE DAN BAHAN}

Jenis penelitian ini adalah observasional deskriptik dengan pendekatan cross sectional study. Penelitian ini dilakukan di apotek rawat jalan Rumah Sakit Umum Daerah Labuang Baji Makassar. Pengumpulan data dilakukan pada bulan Juli 
- Agustus 2017. Populasi adalah resep pasien anak rawat jalan yang menebus obat di Apotek RSUD Makassar tahun 2017. Data populasi pasien anak bulan Januari - Juni 2017 berjumlah 1440 pasien (rata-rata 240 pasien perbulan). Sampel sebanyak 150 orang yang ditentukan secara probability sampling. Penentuan jumlah sampel menggunakan rumus Slovin. Teknik pengumpulan data menggunakan lembar pengumpul data, Pengumpulan data secara prospektif. Observer mengamati di pagi hari, semua data yang relevan dari resep pasien anak yang masuk di apotek rawat jalan RSUD Labuang Baji Makassar selama periode penelitian dimasukkan ke dalam lembar observasi yang telah dibuat kemudian dilakukan pengkajian medication error fase compounding. Data pengamatan untuk fase compounding diperoleh dari pengamatan langsung terhadap dispenser (tenaga teknis kefarmasian dan apoteker) dalam melakukan penyiapan dan penyerahan obat ke pasien. Data yang telah dikumpulkan selanjutnya diolah dan dianalisis dengan cara menghitung jumlah ME fase compounding dari setiap lembar resep dan ditentukan jumlah dan persentasenya, yang disajikan dalam bentuk tabel. Pengolahan dan analisis data dilakukan dengan komputer menggunakan microsoft exel for windows.

\section{HASIL DAN PEMBAHASAN Hasil Penelitian}

Dari penelitian yang telah dilakukan di RSUD Labuang Baji Makassar mengenai ME Pada Pasien Anak Di Rumah Sakit Umum Daerah Labuang Baji Makassar, diperoleh data sebagai berikut :

Tabel 1. Bentuk-bentuk ME fase compounding pada pasien anak rawat jalan di RSUD Labuang Baji Makassar periode Juli - Agustus 2017 ( $\mathrm{n}=150)$.

\begin{tabular}{|c|c|c|c|}
\hline No. & Parameter yang dinilai & Jumlah kejadiaan & Persen $(\%)$ \\
\hline 1. & Kebersihan alat dan meja meracik & 29 & 19,33 \\
\hline 2. & $\begin{array}{l}\text { Obat tumpah pada saat pembuatan } \\
\text { kapsul /puyer }\end{array}$ & 22 & 14,66 \\
\hline 3. & $\begin{array}{l}\text { Tidak mencuci tangan /memakai } \\
\text { sarung tangan pada saat meracik obat }\end{array}$ & 29 & 19,33 \\
\hline 4. & $\begin{array}{l}\text { Tablet yang seharusnya tidak digerus } \\
\text { seperti tablet salut }\end{array}$ & 0 & 0 \\
\hline 5. & $\begin{array}{l}\text { Perhitungan obat yang kurang akurat } \\
\text { (seperti dibelah) }\end{array}$ & 20 & 13,33 \\
\hline 6. & $\begin{array}{l}\text { Dosis kurang karena menempel pada } \\
\text { mortir dan blender }\end{array}$ & 20 & 13,33 \\
\hline \multirow[t]{2}{*}{7.} & Meracik menggunakan blender & 17 & 11,33 \\
\hline & Jumlah & 137 & \\
\hline
\end{tabular}

\section{Pembahasan}

Medication error fase compounding pada penelitian ini terdapat 7 parameter yang dinilai. Dari 150 lembar resep yang diteliti ditemukan compounding error sebesar 18, 97 $\%$ (tabel 4), meliputi kebersihan alat dan meja meracik sebanyak $19,33 \%$, obat tumpah pada saat pembuatan kapsul/puyer sebanyak $14,67 \%$, tidak mencuci tangan/memakai sarung tangan pada saat meracik obat sebanyak $19,33 \%$, perhitungan obat yang kurang akurat (seperti dibelah), dosis kurang karena menempel pada mortir dan blender masing-masing sebanyak 13,33\%, dan meracik menggunakan blender sebanyak $11,33 \%$.

Pada parameter kebersihan alat dan meja meracik, dan tidak mencuci tangan/memakai sarung tangan pada saat meracik mempunyai hasil yang sama masingmasing sebesar (19,33\%). Dalam kebersihan, Farmasis dan tenaga teknis kefarmasian (TTK) sebaiknya mempunyai program secara kontinyu untuk membersihkan peralatan yang digunakan dan peralatan yang mendukung praktek peracikan obat, prosedur untuk kebersihan sebaiknya ditulis secara detail untuk meminimalkan kontaminasi, termasuk di dalamnya prosedur perlengkapan 
personel saat melakukan peracikan obat meliputi penggunaan masker, sarung tangan, baju (Pedoman FDA, 2005). Kurang terjaga kebersihannya dapat menimbulkan interaksi dengan bahan obat yang sudah diracik dan yang akan diracik. Hal ini dapat berpotensi menimbulkan compounding error. Karena hal yang penting dalam proses peracikan obat adalah mempunyai standar minimum untuk personel, fasilitas, kebersihan, peralatan dan dokumentasi peracikan obat. Standar personel yaitu menjamin kualitas personel dan obat yang diracik. (Allen, 2010).

Selanjutnya fase compounding error adalah meracik menggunakan blender (11.33\%). Pada pedoman FDA (2005) tidak tercantum peralatan peracikan seperti blender, peralatan yang digunakan sebaiknya peralatan baku seperti lumpang dan mortir. Blender memiliki bagian yang terbuat dari logam yang dapat bereaksi dengan zat obat sehingga dapat menimbulkan potensi terjadinya ME. Selain itu peracikan obat menggunakan blender akan berpotensi menyebabkan dosis obat akan berkurang karena tertinggal pada bagian-bagian blender $(13,33 \%)$ terutama bagian bawah yang sulit untuk dijangkau, apalagi untuk obat yang memang dosisnya sudah kecil.

Pada parameter obat tumpah pada saat pembuatan kapsul/puyer sebanyak $14,66 \%$, ini dapat menyebabkan dosis berkurang yang pada akhirnya mempengaruhi tercapainya efek yang diinginkan. Demikian pula pada perhitungan obat yang kurang akurat (seperti dibelah) $(13,33 \%)$, ini juga dapat mempengaruhi dosis (bisa kurang atau lebih) sehingga berpotensi menimbulkan ME yang sebetulnya dapat dicegah.

\section{DAFTAR PUSTAKA}

Allen L. V. 2003. Pharmaceutical Compounding-Nonsteril Preparations, United Stated Pharmacopeia Chapter 795, Secundum Artem, USA.

Allen, Jr. L.V. 2010. Quality improvement in pharmaceutical compounding. International Journal of Pharmaceutical Compounding, 14(3), p.180.

Ceci, A., Baiardia, P., Bonifazib, F., Giaquintoc, C., Pe nad, MJM., Mincaroneb, P., Nicolosie, A., Sturkenboomf, M., Wongg, I. 2009. TEDDY NoE project in the framework of the EU Paediatric Regulation, Pharmaceuticals Policy and Law 11, 13-21

Food and Drug Administration (FDA). 2005. Employee Health and Personal Hygiene Handbook

Hinlandou, E.Y. 2008. Evaluasi Medication Error Resep Racikan Pasin Pediatrik Di Farmasi Rawat Jalan Rumah Sakit Bethesda, Skripsi.

Romano, MJ., Dinh, A 2001. A1000-fold overdose of clonidine caused by a compounding error in a 5 year-old child with attention deficit/hyperactivity disorder. Pediatrics, experience and reason, 471-472. 